\title{
ІНТЕГРУВАННЯ ПЕДАГОГІЧНИХ ІДЕЙ А. С. МАКАРЕНКА В ДІЯЛЬНІСТЬ СУЧАСНИХ ЗАГАЛЬНООСВІТНІХ ТА ВИЩИХ НАВЧАЛЬНИХ ЗАКЛАДІВ
}

Волікова М. М. Інтегрування педагогічних ідей А. С. Макаренка в діяльність сучасних загальноосвітніх та вищих навчальних закладів.

У статті проаналізовано педагогічні ідеї та погляди видатного українського педагога А. С. Макаренка в контексті сучасних освітніх реалій: усебічний розвиток і самоствердження особистості, формування особистісної зрілості, особливості професійної діяльності педагога в контексті гуманістичної освіти. 3'ясовано, наскільки думки А. С. Макаренка про педагогічну техніку та майстерність є актуальними на сьогодні. Обгрунтовується думка про те, що дійсний шлях розвитку виховної та освітньої системи XXI століття має бути діалектичним розвитком педагогічної теорії та практики XX століття.

Ключові слова: інтеграція, педагогічна спадщина А. С. Макаренка, освіта, виховання.

Воликова М. Н. Интегрирование педагогических идей А. С. Макаренко в деятельность современных общеобразовательных и высших учебных заведений.

В статье проанализированы педагогические идеи и взгляды выдающегося украинского педагога А. С. Макаренко в контексте современных образовательных реалий: всестороннее развитие и самоутверждение личности, формирование личностной зрелости, особенности профессиональной деятельности педагога в контексте гуманистического образования. Выяснено, насколько мысли А.С. Макаренко о педагогической технике и мастерстве являются актуальными на сегодня. Обосновывается мысль о том, что действительный путь развития воспитательной и образовательной системы XXI века должен быть диалектическим развитием педагогической теории и практики XX века.

Ключевые слова: интеграция, педагогическое наследие А.С. Макаренко, образование, воспитание.

Volikova M. N. The integration of pedagogical ideas of A. S. Makarenko in the activities of modern comprehensive and higher education institutions.

The article analyzes the pedagogical ideas and views of outstanding Ukrainian educator A. S. Makarenko in the context of contemporary educational realities: comprehensive development and self-esteem, the formation of personal maturity, peculiarities of professional activity of a teacher in the context of a humanistic education. It was clarified how the thoughts of A.S. Makarenko about teaching technique and skill are current today. The idea that the actual path of the educational system development of the twenty-first century should be the dialectical development of pedagogical theory and practice of the twentieth century has been substantiated.

Key words: integration, pedagogical heritage of A. S. Makarenko, education, upbringing.

Інтегрування української педагогічної освіти до загальноєвропейського та світового освітнього простору вимагає усвідомлення концептуальних засад i принципів сучасної професійно-педагогічної підготовки як майбутнього вчителя загальноосвітньої школи, так і викладача вищого навчального закладу. Нині історико-педагогічний аналіз розвитку освіти щодо зміни філософсько-освітньої парадигми свідчить, що на її специфіку на різних етапах 
розвитку суспільства мали вплив переважно загальносистемні соціальні чинники. Саме останні визначали той синтез концептуально-освітніх ідей та цінностей виховання інституційних, фундаментальних, праксеологічних характеристик освіти, які нині формують оригінальну філософсько-освітню парадигму. Задля ефективного розв'язання сучасних освітніх проблем залишається актуальним звернення до педагогічного досвіду та видатних науковців, педагогів-практиків, які заклали основи теорії навчання та виховання. У цьому інтеграційному процесі педагогічна спадщина видатного українського педагога Антона Семеновича Макаренка (1888-1939рр.) слугує надійним критерієм ефективності та переваг у системі освіти. Видатного педагога цікавили найактуальніші навчальні та виховні проблеми, а саме: розвиток і самореалізація кожної особистості, формування поколінь, здатних навчатися впродовж життя, особливості комунікативних можливостей вчителя, особливості розвитку учнівського колективу, володіння педагогічною технікою, без якої не може бути гарного вихователя - майстра тощо.

Сучасний науковий дискурс репрезентує численні наукові дослідження в галузі макаренкознавства. Так, проблеми теорії та практики А.С. Макаренка представлено в роботах вітчизняних (І. Гетманець, М. Гетманець, Н. Дічек, І. Зязюн, С. Карпенчук, М. Окса, М. Ярмаченко та ін.) та зарубіжних (В. Беляєв, Л. Гриценко, I. Козлов, В. Кумарін, С. Невська, А. Фролов, О. Ілалтдінова, Т. Корабльова, З. Вайтц, В. Зюнкель, Х. Расмуссен, Л. Фрезе, Г. Хілліг та ін.) науковців. У нашому дослідженні цінними є праці, присвячені питанням загальної та професійної підготовки майбутніх фахівців (П. Воловик, С. Гончаренко, І. Зязюн, М. Махмутов, Н. Ничкало), інтеграційних процесів в освіті (М. Берулава, В. Безрукова, Л. Васіна, Р. Гуревич, І. Козловська, Р. Мустафіна, Л. Сліпчишин, Я. Собко, Н. Тализіна, Ю. Тюнников, Т. Якимович та ін.). Однак проведений аналіз наукової літератури, засвідчив, що на сьогодні існують певні суперечності між традиційною оцінкою макаренківської педагогічної концепції і сучасним баченням їі змісту, зокрема в питаннях навчання та виховання молодого покоління. Через це окреслена проблема потребує подальшого розроблення й вивчення.

Метою статmі: на основі аналізу науково-публіцистичної спадщини А. С. Макаренка показати, що ідеї та погляди видатного педагога XX століття можуть слугувати методологічною основою для розроблення змісту середньої та вищої освіти.

Проблема виховання й навчання молодої людини, яка б відповідала сучасним освітнім запитам, є вкрай важливою. Кожне століття формує свої виховні еталони, але вічними залишаються ідеї, цінності та погляди. У зв’язку з цим педагогічні ідеї, запропоновані А. С. Макаренком, розглядаються освітянами 3 позицій контекстуально-інтеграційного підходу, на основі якого можна відобразити педагогічний досвід у системі загальнопедагогічної підготовки як сучасного вчителя, так і викладача ВНЗ. Сучасні науковці І. Зязюн, І. Кривонос, Н. Тарасевич у своїх розвідках слушно зауважують, що: «у макаренківській спадщині криються величезні резерви перетворень усієї шкільної справи, резерви більш якісного виконання програми навчання й виховання дітей та молоді, що відповідає потребам часу» [1, с. 42].

Відомий український макаренкознавець академік Н. Ярмаченко уважає: «творча спадщина А. С. Макаренка ніяк не обмежується часовими рамками свого створення, тобто 20-30-ми роками XX століття. Вона є справжньою науковою педагогікою, яка спрямована в майбутнє. У ній фактично нічого немає застарілого. Усі узагальнення й висновки Антона Семеновича не тільки можуть, а й повинні бути застосовні в сучасних умовах, відповідно до вимог реформи загальноосвітньої і професійної школи...» [11, с. 189]. Таку ж позицію щодо 
значущості науко-педагогічної спадщини А. С. Макаренка у навчально-виховному процесі демонструє багато науковців. В.Сластьонін уважає, «...спадщину Антона Семеновича явищем світової педагогічної культури, яка склалася в результаті багаторічної безкомпромісної боротьби за утвердження принципово нового погляду на виховання підростаючої людини, за утвердження науки про її соціалізацію та розвиток» [9, с. 5]. Наведені вище цитати, на наш погляд, допоможуть інтегрувати низку педагогічних ідей та положень А. С. Макаренка в діяльність сучасного загальноосвітнього та ВНЗ.

Передусім слід зазначити, що поняття «інтеграція» не нова категорія в системі освіти. У сучасній науковій літературі пропонується велика кількість визначень поняття «інтеграція» та всі вони, спираючись на первинний смисл (від лат. слів integr - цілий, повний та integratio - доповнення) підкреслюють, що «інтеграція»- це відновлення, доповнення, об’єднання частин у ціле. У нашому випадку ближчим є тлумачення терміна «інтеграція» дослідницею I. Козловською, яка трактує його як систему знань, форм, методів і технологій навчання. Спираючись на різні інтерпретації терміна «інтеграція», Л. Масол виводить класифікацію інтеграцій. Серед видів інтеграцій науковець виокремлює такі різновиди, як: «інтеграція форм організації навчання й виховання, що реалізується в межах інтегрованого заняття, та інтеграція способів взаємодії педагога й студента, що вмтлумачується як інтегративна педагогічна технологія» [8, с. 8]. Отже, поняття інтеграція науковцями розглядається як процес становлення цілісності, взаємопроникнення елементів одного об’єкта до структури іншого, підкреслюють, що її результатом є не просто сума об’єктів чи поліпшення їх якості, а новий об’єкт з новими властивостями [2, с. 13].

Аналіз історико-педагогічних досліджень показує, що феномен інтеграції в навчальному процесі не новий і був предметом особливої уваги освітян у всі історичні періоди. Так, у 20-30 роках XX століття науковцями розпочинаються інтенсивні пошуки нових педагогічних технологій. Термін «технологія» в радянську педагогіку ввів саме А. С. Макаренко, як стрижень педагогічної системи. У цьому розумінні педагогічна спадщина А. С. Макаренка, залишена у вигляді літературних творів, лекцій, стенограм, може надати практичну допомогу педагогу-початківцю в пізнанні певних питань, які стосуються виховної техніки. Ще на початку XX століття у своїх наукових розвідках А. С. Макаренко наголошував: «Я певен, що в майбутньому в педагогічних вишах неодмінно викладатимуть і постановку голосу, і пози, і володіння своїм настроєм. I без цього я не уявляю собі роботи вихователя. Звичайно, постановка голосу має значення не тільки для того, щоб гарно співати чи говорити, а й для того, щоб уміти як найточніше, владно висловлювати свої думки та почуття. Все це питання виховної техніки» [7, с. 111]. Ця розлога цитата є свідченням того, що педагогічна система А. С. Макаренка піддається інтегруванню, моделюванню, прогнозуванню, передбаченню нестандартних моделей систем і підструктур з урахуванням кінцевого прогнозованого результату та відповідних результативних зрізів. Використовуючи сучасні технології навчання, у Криворізькому педагогічному інституті кожному студенту/студентці надається можливість розвивати власний інтелект, здібності до саморозвитку, самоорганізації, бути мобільним та конкурентоспроможним на ринку праці.

Беззаперечне значення педагогічний ідей та праць А. С. Макаренка в розробленні цілей виховання: «Для кожної епохи і для кожного покоління, - вважав А. С. Макаренко, мета виховання повинна визначатися діалектично, тобто ії̈ потрібно знаходити у вимогах суспільства в даний час» [4, с. 425]. Наголошуючи на важливості визначення мети виховання, А. С. Макаренко наполягав: «Я під цілями виховання розумію програму людської особи, проблему людського характеру, причому в поняття характеру я вкладаю весь зміст 
особистості, тобто і характер зовнішніх проявів, і внутрішньої переконаності, і політичне виховання, і знання, і геть усю картину людської особи; я вважаю, що ми, педагоги, повинні мати таку програму людської особи, до якої ми повинні прагнути» [3, с. 105]. Зрозуміло, що педагог обмірковує глобальну проблему освітньо-виховного процесу, яка є актуальною в усі періоди розвитку педагогічної науки і практики. Тож, у наведених вище міркуваннях мета виховання постає в єдності із завданнями, які кожна історична епоха ставить перед суспільством, а суспільство - перед школою чи ВНЗ.

Як відомо, А. С. Макаренко сам мріяв про те, щоб написати книгу «Педагогіка» й ставився до цієї галузі знань з особливою повагою і пошаною, і водночас вимогливо до тих, хто їх продукував: «Я особисто переконаний ось в чому: коли ми візьмемо звичайну школу, віддамо їі до рук добрих педагогів, організаторів, вихователів, і ця школа житиме 20 років, то протягом цих 20 років в добрих педагогічних руках вона повинна пройти значний шлях, що система виховання на початку і в кінці повинна дуже відрізнятися одна від одної. Взагалі педагогіка $є$ найбільш діалектична, рухлива, дуже складна й різноманітна педагогічна наука. Ось це твердження і є основним символом моєї педагогічної віри» [5, с. 104]. Ці міркування характеризують А.С. Макаренка як людину, яка з болем переживала за всі ті зміни, які відбувалися в педагогічній теорії та практиці першої половини ХX століття. Окрім цього, педагог вирізнявся своєю прогностичністю, далекоглядністю, вмінням мислити перспективно. У цьому і є його унікальність та неповторність в історії педагогічної думки.

Ще однією вагомою заслугою А. С. Макаренка було правильно організоване виховання культури взаємин статей, а саме стосунки колоністів (дівчат і хлопців). Основний принцип таких взаємин полягав у тому, що кохання має закінчуватися шлюбом. У своїх спогадах педагог зауважував: «...3 хлопцями легше вести бесіди на делікатні теми, ніж 3 дівчатами, які все заперечують, що їм хтось подобається» [10, с. 68]. Проте, на думку А. С. Макаренка, правильне виховання має бути тільки спільним: «Як у житті люди разом, так і виховуватися вони повинні разом, і тоді нормально буде йти життя дівчат та юнаків» [6, с. 127]. Аналізуючи погляди видатного педагога на проблему спільного виховання дівчат і хлопців, можна з упевненістю стверджувати, що виховання за А. С. Макаренком - це не навчання молодого покоління статевої моралі, де на першому місці є біологічні бажання $\mathrm{i}$ потяги людини, а виховання в майбутньому чоловікові вміння бути порядним батьком, мужчиною, а в майбутній жінці- вміння бути матір'ю, жінкою в усіх численних виявах життя. I в кожному випадку неодмінно-бути самим собою, тобто людиною неповторної індивідуальності.

Багато цінних педагогічних порад А. С. Макаренко надавав щодо формування педагогічного колективу. Так, у лекції «Педагогіка індивідуальної дії» педагог доходить висновку, що «колектив педагогів повинен бути дібраний не випадково, а утворений розумно. Тут повинна бути певна кількість старих, досвідчених педагогів, і неодмінно повинна бути дівчина, яка тільки що закінчила педагогічний виш, яка ще ступати не вміє. Але вона повинна бути неодмінно. Саме тут відбувається містерія педагогіки, коли така дівчина приходить в старий колектив і педагогів і вихованців, починається невловно тонка історія, яка визначає успіх педагогічний» [7, с. 114]. Педагога непокоїло й те, що колективи вчителів складаються здебільшого стихійно, випадково, із тих людей, які пропонують свої послуги. 3 огляду на складність проблеми у життєвих планах А. С. Макаренка були наміри відкрити закони побудови педагогічного колективу, але йому так i не вдалося цього здійснити.

Ідеї А. С. Макаренка в царині самоврядування отримують нові імпульси для реалізації 
в учнівському та студентському середовищі. Уже в перші роки роботи в колонії імені М. Горького (1920-1928рр.) А. С. Макаренко, зважаючи на контингент своїх вихованців, займався активними пошуками способів подолання таких негативних явищ, як кругова порука, ворожнеча і бійки, зосередження надмірної влади в руках старших колоністів й одержання ними певних привілеїв тощо. Вагомої рролі 3-поміж таких способів педагог надавав залученню колективу колоністів до вирішення соціально значущих задач й організації його багатоманітних відносин з іншими колективами. Таке розуміння сутності колективу та його виховних функцій зумовило його погляди на сутність поняття «самоврядування» та знайшло своє відображення в художніх творах, головним чином, у «Педагогічній поемі», «Прапорах на баштах», у «Книзі для батьків» численних статтях, які представляють собою оригінальну, витончену педагогічну систему. Розроблені та впроваджені на практиці А. С. Макаренком теоретичні засади та методичні положення в галузі самоврядування можна актуалізувати в сучасній педагогічній практиці, якщо: створити необхідні умови для реалізації відповідних прав і обов'язків всіх учасників навчального процесу; забезпечити постійне зростання соціальної значущості й моральної цінності роботи студентів в органах самоврядування; залучити їх до реального управління своїм колективом, розвивати в них соціально-трудову активність і самостійність. Нині самоврядування як засіб соціалізації особистості потрібно як учням, так студентству, тому що це - практична школа для тих, хто бажає спробувати себе в ролі керівника, адміністратора, лідера.

Отже, усе зазначене вище дозволяє визначити, що педагогічні ідеї та погляди А. С. Макаренка можуть слугувати міцним підгрунтям для забезпечення ефективного функціонування як загальноосвітніх, так і вищих навчальних закладів. Застосування ідей А.С. Макаренка та втілення їх у діяльність освітніх закладів наочно свідчить про подальший розвиток педагогічної теорії та практики, про іï зростаючий зв’язок із життям нашого суспільства. Як показує навчально-виховна практика, теорія А.С. Макаренка діє та використовується і в Криворізькому педагогічному інституті безвідмовно, слід тільки враховувати важливу пораду макаренкознавців: «брати в А.С. Макаренка треба не конкретний, готовий досвід, а ідею його методів і підходів» [11].

Подальше вивчення питань щодо виховання дітей та молоді в педагогічній практиці А. С. Макаренка плануємо спрямувати на вивчення теоретичних і методологічних основ його доробку.

\section{Література}

1. Зязюн І. А. Гуманістична сутність майстерності А. Макаренка - вихователя / І. А. Зязюн, І. Ф. Кривонос, Н. М. Тарасевич // Педагогіка і психологія. - 1998. - №1. - С. 1843. 2. Іванчук М. Г. Інтегроване навчання: сутність та виховний потенціал. (Виховання особистості молодшого школяра в умовах інтегрованого підходу до навчання)/ М. Г. Іванчук. - Чернівці : Рута, 2004. - 360 с. 3. Макаренко А. С. Проблеми шкільного радянського виховання / А. С. Макаренко : Твори в семи томах. - Т. 5. - Київ : Рад. школа, 1954. - 484 с. 4. Макаренко А. С. Мої педагогічні погляди / А. С. Макаренко: Твори в семи томах. - Т. 4. - Київ : Рад. школа, 1954. - 428 с. 5. Макаренко А. С. Загальні питання теорії педагогіки / А. С. Макаренко: Твори в семи томах. - Т. 5. - Київ : Рад. школа, 1954. - 482 с. 6. Макаренко А. С. С любовью и тревогой : сборник / А. С. Макаренко; сост., вступ. ст., прим. А. К. Романовского, А. Т. Губко. - Київ : Изд-во УСХА, 1989. - 368 с. 7. Макаренко А. С. Вибрані педагогічні твори // А. С. Макаренко. - Київ : Рад. шк., 1947. 282 с. 8. Масол Л. М. Зміст загальної мистецької освіти в Україні й за рубежем : Проблеми 
виховання / Л. М. Масол // Педагогіка i психологія. - 2001. - № 3-4. - С. 69-79. 9. Сластенин В. А. Макаренко как теоретик воспитания / В. А. Сластенин // Педагогическое образование и наука. - 2008. - № 3. - С. 5-7. 10. Хархан Г. Д. Виховання сім'янина в педагогічній спадщині А.С. Макаренка / Г. Д. Хархан // Соціальна педагогіка: теорія та практика. - 2010. - № 1. - С. 66-71. 11. Ярмаченко Н. Д. Педагогическая деятельность и творческое наследие А. С. Макаренко : [книга для учителя] / Н. Д. Ярмаченко. - Київ : Рад. школа, 1989. - 191 с.

УДК: 378. 011. 3-051: 80

Дмитро Левчук

\section{ФОРМУВАННЯ МОВЛЕННЕВОЇ КУЛЬТУРИ МАЙБУТНІХ УЧИТЕЛІВ ФІЛОЛОГІЧНИХ СПЕЦІАЛЬНОСТЕЙ ЯК НАУКОВО-ПЕДАГОГІЧНА ПРОБЛЕМА}

Левчук Д. В. Формування мовленнєвої культури майбутніх учителів філологічних спеціальностей як науково-педагогічна проблема.

У статті розглядається проблема формування мовленнєвої культури майбутніх учителів філологічних спеціальностей, з'ясовується сутність поняття «культура мовлення». Звертається увага на основні функції педагогічного мовлення та проблеми студентів, з якими вони стикаються у процесі мовлення.

Ключові слова: культура мовлення, мова, мовленнєва культура, функції мовлення, майбутні вчителі філологічних спеціальностей.

Левчук Д. В. Формирование культуры речи будущих учителей филологических специальностей как научно-педагогическая проблема.

В статье рассматривается проблема формирования культуры речи будущих учителей филологических специальностей, выясняется сущность понятия «культура речи». Обращается внимание на основные функции педагогической речи и проблемы студентов, с которыми они сталкиваются в процессе речи.

Ключевые слова: культура речи, язык, речевая культура, функции речи, будущие учителя филологических специальностей.

Levchuk D. V. Speech culture formation of future teachers of philology as a scientific and pedagogical problem.

The article deals with the problem of speech culture formation of future teachers of philologycal specialities; the concept of the term "culture of speech" has been defined. Attention to the basic functions of pedagogical speech and educational problems which students face during speech process is drawn.

Key words: speech culture, language, speech function, future teachers of philology.

Розбудова національної системи освіти в умовах становлення України як самостійної незалежної держави з урахуванням кардинальних змін в усіх галузях суспільного життя, історичних викликів XXI століття вимагає критичного осмислення досягнутого i зосередження зусиль та ресурсів на розв’язанні найбільш гострих проблем, які стримують розвиток освітньої галузі, не надають змоги забезпечити нову якість освіти, адекватну нинішній історичній епосі. Однією з цих проблем є поступове зниження рівня мовленнєвої 